\title{
Amellerin zahirî ve batınî yönlerini etkileyen iki kavram: Niyet ve ihlâs
}

\begin{tabular}{rll}
\hline Araştırma Makalesi & DOI: https://doi.org/10.51177/kayusosder.823097 \\
Gönderi Tarihi: 08.11.2020 & Kabul Tarihi: 20.12.2020 & Online Yayın Tarihi: 31.12.2020 \\
\hline
\end{tabular}

\begin{abstract}
Özet
Niyet ve ihlâs kavramları kişinin hayatına yön veren, dinî ritüellerine mana katan, duygu ve düşünce yapısını şekillendiren önemli olgulardandır. Bu çalışmamızda dini yaşantı ve uygulamalarda önemli bir yere sahip olan bu kavramlar Tasavvuf ilmi çerçevesinde ele alınacaktır. Niyet ve ihlâs kavramlarını tek tek ele alıp değerlendirildikten sonra bu iki kavramın birbiriyle olan ilişkilenme derecesinin etkinliği incelenecektir.

Bireylerin niyetleri doğrultusunda oluşan davranış ve duygular onların ibadet boyutlarındaki hal ve durumlarını etkileyip, ihlâsa ulaşma konusunda zemin hazırlamaktadır. Bu açıdan değerlendirdiğimiz bu tasavvufî kavramların ilk önce sözlük ve terim manaları ele alınacak, Kur'an-1 Kerim ve Hadis-i Şeriflerdeki önemi vurgulanacaktır. Sonrasında tasavvuf ilminin öncülerinin eserleri incelenerek niyet ve ihlâs kavramları arasındaki bağlantı ve hayata iz düşümü zahirî ve batinî yönlerden birlikte değerlendirilecektir.
\end{abstract}

Anahtar Kelimeler: Niyet, ihlâs, tasavvuf, sufî

\section{Two concepts of actions affecting non-esoteric and esoteric aspects: Intention and Sincerity(ikhlâs)}

\begin{abstract}
The concepts of intention and ihlâs which are significiant phenomenon give shape to life of humans, give meaning to their religious activities and affect their feelings and thoughts. In this study, these concepts which have important roles in religious life and practices will explain in detail in terms of the role of tasawwuf discipline. After terms of intention and ihlâs are evaluated one by one, it will be examined the correlation between these items and make rating system according to explanations and experiences.

According to individuals' intention, behaviors, feelings and their religious activities can change and also may reach ihlâs point in their life because of this situation. Firstly, these concepts will be defined, then emphasized the importance in Quran and Hadiths, lastly the correlation between intention and ihlâs will be evaluated from thoughts and ideas of popular sufis in tasawwuf field.
\end{abstract}

Key words: Intention, Ihlâs, Tasawwuf, sufî

${ }^{1}$ Doktor Öğretim Üyesi, Kayseri, Üniversitesi, Develi İslamî İlimler Fakültesi, elifigalci@kayseri.edu.tr 


\section{Giriş}

Niyet; kişilerin amellerini, kalbî hissiyatlarını ve dahi düşüncelerini etkileyen, bilinçli ya da bilinçsiz olarak kişilerin yaşantılarında iz bırakan, hissedilen ve bireylerin yaşantılarını anlamlandıran soyut bir kavramdır. Kişi niyetleri doğrultusunda düşünce, fiil ve davranışlarına şekil vermekte, amellerini bu doğrultuda hâlis ya da habis yapabilmektedir. Nitekim Peygamber Efendimiz(sav) “Ameller niyetlere göredir" (Müslim, İmare, 155) buyruğuyla bu önemin altını çizmektedir.

İhlâs kavramı ise dinî yaşantının özü, amellerin manası ve kalpdeki niyetin dışa yansımasıdır. İbadetlerdeki samimiyet ne kadar içten ve doğal olursa Yaratıcımıza ulaşma da o derece etkin ve anlamlı olacaktır. Tasavvuf da ayrı bir öneme sahip olan ihlâs kavramı zâhirî anlayıştan ziyade rûhanî bir anlam içermekte, derin manasıyla da amellerin uygulanmasını etkilemektedir.

Niyetlerin rol aldığı, kişiyi ihlâslı ya da ihlâssız yapma noktasında kilit bir role sahip kıldığı, niyetlerin amelleri, amellerin niteliğini de ihlâsın derecesinin belirlediği bu iki kavramı Tasavvuf ekollerinin önde gelenlerinin perspektifinden ele alarak niyet ve ihlâs kavramları arasındaki bağlantıyı inceleme gayretinde olacağız. Niyet ve ihlâs kavramlarının terimsel ve sözlük manalarını verdikten sonra, zahirî ve batinî manalarıyla derinlemesine açılayacak, tasavvufî değerlendirmede tasavvuf ilminin ileri gelen sufîlerinin görüş ve düşünceleri çerçevesinde ele alıp çalışmamız sonuçlandırılacaktır.

\section{Niyet: Tanımı, unsuru ve hakîkati}

Niyet kavramını ele almak hem kişinin kalbî hem de amelî durumlarını algılamak açısından önem arz etmektedir. Bu iki açıdan değerlendirmek adına niyet kelimesinin sözlük ve sstılah manalarına değinmek, önemi ve hakikati üzerinde durmak, hadis-i şeriflerdeki yerine değinmek ve davranışsal boyutlarda inceleyip sonuç çıkarmak konuya açıklık getirmek adına elzemdir.

Niyet (نبّت kelimesi Arapça'da نية kökünden gelmekte plan, tasarı anlamı içermektedir (Etimoloji, 2020). Bir şeyi yapmayı önceden kurma, zihinde tasarlama, yapmayı aklına koyma, yapmaya karar verme gibi anlamları olan niyet kelimesi lugatî olarak tanımlamalarda yönelmek, ciddiyet ve kararlılık göstermek şeklinde ifade edilmektedir (Kubbealtı Lugatı, 2020).

Niyet kavramını batınî olarak yorumladığımızda da amellerin dayandığı temel niyettir ve niyetin bulunduğu yerin kalb olarak ifade edildiği görülmektedir. Bunun için niyet kalbin kalbi olarak da yorumlanabilir. Niyet, kalbin dizgini, amelin ruhu ve kumandanı, kasdın başlangıcı, konuşma, susma, hareket ve sekenât gibi dışa ait olan fiillerin içidir (Cebecioğlu, 2009, s. 486) şeklinde batınî bir açıklama niyetin hakikatini anlama açısından elzemdir. Dolayısıyla amellerin mana kazanması ve yönünün belirlenmesi, ne için yapıldı̆̆ kişide zuhur eden niyetle olur.

Kişide meydana gelen niyet gizlidir ve aynı zamanda da gaybîdir ve gaybı Allah Teâlâ'dan başka kimse bilemez. Bireyde saklı olan ve sonucunu, yönünü Allah'tan başkasının bilemediği niyet kavramının kilit bir rolü bulunmaktadır ki bu rol bütün farzlardan önce gelen bir farz olmasını kapsamakta, o olmadan hiçbir farz sahih ve geçerli olmaz (Mekkî, 2019, s. 45) düşüncesi hem amelleri hem davranışları hem de tüm fiiliyatların temelini oluşturduğunu göstermektedir.

Her türlü eylem, düşünce ve davranışta irade söz konusudur. İradesiz hiçbir olayın gerçekleşmediği gibi, davranışların rotası da belli olamaz. Bunun için niyeti kulun bir gaye için bir işi yapma iradesi şeklinde yorumlamakta mümkündür. Bu irade ya Allah için olur ya da bir başkası için olur. Bu iradede ki gayeler ya o iş için ya ahiret için ya da dünyalık bir fayda için olabilmektedir (Muhasibî, 2012, s. 237). Önemli olan nokta burada niyetin amacının belli olmasıdır ki rotası belli olanın gideceği yerde belli olabilsin.

Niyet her amelin şartıdır; niyetsiz hiçbir amel geçerli olmaz. Tek başına niyet, başka bir şeye ihtiyaç duymadan geçerli bir amel olur ve niyet mü'minin en hayırlı amellerinden biri olmaktadır (Mekkî, s. 40-41). Böyle bir düşünce olmakla birlikte aynı zamanda yalnız niyet tek başına yeterli bir unsur olmamakla birlikte amelle ilişkisi kişiyi ya kurtuluşa ya da gaflete götürebilecektir. Kurtuluşa götürecek davranışların temelinde hayır niyet hayır düşünce ve hayır amel olmalıdır ki birey gafletten sıyrılabilsin. Niyetin hayırlı olabilmesi için kalbi harekete geçirmesi ve tüm amellerini kalbî olarak yapabilmesi gelmektedir. Çünkü en kilit organ "kalb" dir ve tüm organlar ona tabiidir (Gazzâlî, 2012, 4/684). 
Kayseri Üniversitesi Sosyal Bilimler Dergisi, Cilt 2, Sayı: 2, Aralık 2020, 114-122

Kayseri University Journal of Social Sciences, Vol 2, No: 2, December 2020, 114-122

Peygamber Efendimiz (sav) şöyle buyuruyor; "Ameller niyet iledir ve herkese neyi niyet etmişse o vardır. Kim ki Allah ve Resulü yolunda hicret etmişse, hicreti Allah ve Resulünedir. Kim ki dünyalı̆̆ elde etmek veya bir kadinla evlenmek için göç etmişse onun da hicreti niyet ettiği şeyedir" (Buhari, Iman, 41).

Diğer bir hadis şerifte de "Allah-u Teâla sizin suret ve mallarınıza değil, niyet ve amellerinize bakar" buyurmaktadır (Müslim, Birr, 33).

Amellerin direği niyettir. Amel, hayır olması için halis niyete muhtaçtır (Müslim, İmare, 45).

$\mathrm{Bu}$ hadis-i şeriflerden anlaşıldığ 1 üzere yola çıkmadan önceki düşünce, duygu ve fiiliyatı etkileyen kalpteki niyet son derece önemli olmakla birlikte kişinin amelinin derecesini ve hatta yönünü belirleyen bir kavram olarak karşımıza çıkmaktadır. Niyet kavramının yönünü belirleyebilmek ve sırat1 müstakim çizgisinde tutabilmek içinde hakikatine ererek yaşantıya dökmek gerekmektedir.

Niyetin hakikatini anlayabilmek için de ilim ve ameli anlamamız gerekmektedir. Bunların arasında da ilk önce ilim sonra da amel gelmektedir. Amel her zaman ilme tabiidir. Bir şeyi yapabilmek için kişinin bilgi sahibi olması gerekmekte sonrasında onu istemesi ve icraata dökebilmesi için de o fiili gerçekleştirecek ölçüde gücünün olması lazım gelmektedir. İlim, irade ve amel bir arada bulunmadığı takdirde ameller hayata geçmiş olamaz. Bu anlatımdan da anlaşılacağı üzere ilim, irade ve amel niyetin hakikatini kavrama açısından kilit kavramlardandır.

Niyetin hakikat ve çeşitlerini bilmek bireyi niyetleri doğrultusunda daha bilinçli kılarken, iradî yönde de etkisinin artacağı iyi amellere doğru hazırlayabilmektedir. Düşünce ve duyguların davranışlarımızı ne ölçüde etkilediği bilimsel gerçeğiyle (Görmez, Sivri, 2019) niyetin öz manasının da amellere hangi derecede etki edeceği dinî açıdan oldukça önemli bir durumdur. Nitekim büyük zatlardan Abdullah bin Mübarek'in (v. 181/797) söylediği gibi "Nice küçük ameller vardır ki, niyetler onları büyültür. Nice büyük görünen ameller vardır ki, niyetler onlarl küçültür”" (Gazzalî, 4/682) niyetlerin niteliğinin amelleri derecelendirdiği görülmektedir.

Niyetin akıbetinin iyi olması, davranışlarımızı Rahmanî olarak yönlendirmesi ve amellerimizi salih amel statüsüne çıkarabilmesi için çeşitli özelliklerle donatılmalıdır. Sadece dil ile ikrardan ziyade kalbî olarak niyet ameli süsleyebileceği gibi bedenen ve ruhen de etkileşimin yüksek olmasını sağlayacaktır. Riyadan uzak olarak sırf Allah rızasını yerine getirmek, Allah-u Teâlâ'yı hoşnut edebilmek olmalıdır ki niyetlerde ameller de yerine hakkıyla ulaşabilsin.

İnsanın yaptı̆̆ 1 her işinde hâlis niyet bulunmalı; her türlü tasarrufu, hareketi, gayreti, bir şeyi yapması ve yapmaması güzel niyetle olmalıdır; çünkü insanın bir şeyi yapması ya da onu terk etmesi kulun hesaba çekileceği amellerin temellerini oluşturan iki temeldir. Bu yüzden bu iki şey mutlaka niyet ve ihlâsa dayalı olarak yapılmalıdır (Mekkî, s. 56).

Niyetlerin dayanağının ilk temeli Kur'an ve Sünnet olmalıdır. Onların koyduğu çerçevede niyetleri düzenlemek fikrî ve amelî dünyayı etkileyecektir. Bu temellere dikkat edilerek yapılacak niyetlerin Rahmanî mi yoksa nefsanî mi olduğuna dikkat etmek son derece elzemdir. Esas olan niyetin halis, sadık, saf ve Allah için olması lazımdır (Gazzalî, 4/685). Halis niyetle yapılan tüm davranışlar Allah'a yakınlık sağladığı gibi, Allah'ın rızasına da vesile olmaktadır (Oğuk, 2013, s. 81-112).

Niyetler her daim kişiyi Allah'a yakınlaştıran ön hazırlayıcılardır. Halis olanlar, iyi ve rahmanî olanlar kişiyi ve çevresindekileri olumlu olarak etkilerken, bu özelliklerden uzak Allah kaygısı yaşamayan, nefsanî ya da şeytanî duygu ve düşüncelerle habis niyetleri olan kişilerinde hem kendilerine hem de çevresindekilere zararları oldukça fazla olacaktır. Bundan dolayı niyeti öncelemek gidilen rotanın yönünü belli edecek, cennet ya da cehennem akıbetini hızlandıracaktır. Özetle, amelde niyetin Allah için olması o işte sadece Allah'ın sevabını beklemekle olur (Muhasibî, s. 237). Mekkî'ye göre; "niyetlerin en üst noktası ve ihlâsın zirvesi daima Allah'ın rızası ve O'na yakınlaşma arzusu olmalıdır" (Mekkî, s. 58) düşüncesi diğer tasavvuf ehliyle örtüşerek niyetin temelinin Allah rızası olması gerektiğini vurgulayarak göstermektedir.

İnsanların düşmanı olan şeytan, kullar üzerinde ilk olarak hâkimiyetini niyetlere zarar vererek kalp üzerinde olumsuz yönde kurar. Kulun niyetinde bir tamahkârlık, bir değişiklik meydana geldiği 
anda hemen ona şeytan musallat olur. Aynı şekilde, kulun doğruluktan ve istikametten saptığı ilk nokta da niyette zaaf göstermesidir. Niyette zayıflama olunca nefis kuvvetlenir ve nefsin arzuları kendisine yer bulur (Mekkî, s. 49).

Her mü'minin gayesi muhakkak ki Rabb-ül Âlemini razı etmek, ona layık kul çabasında yaşamak, halis niyetlerle amellerini süslemektir. Lakin zahirî olarak görünen her bir davranış ve fiiliyatın muhakkak ki kalbî bir boyutu söz konusudur. Bu kalbî boyutu ihlâsla cilalamak kişiyi manen ve maddeten eğitecek ve yetiştirecektir. Bundan dolayı niyet ve ihlâs kavramları arasında ki bağlantıyı hem zahiren hem de bâtınen ele almak için ihlâs kavramının manalarını ve 1stılahlarını inceleyerek açılım yapmaya çalışmak ve yaşamda bir örneklem oluşturma faydalı olacaktır.

\section{2. İhlâs: Tanımı, unsuru ve hakîkati}

İhlâs kavramını zahirî ve batinî açıdan değerlendirmeden önce terimsel ve kavramsal olarak anlamlarına değinmemiz yerinde olacaktır. Sözlük manasında genel hatlarıyla bir yol haritası çizmek sonrasında da değineceğimiz ıstılahî tanımlamalar ihlâs kelimesinin özünü anlamamızı sağlayacaktır. $\mathrm{Bu}$ doğrultuda hem lugatî hem deneyimsel manalarına değinerek ihlâs kavramını derinlemesine ele almak gerekmektedir.

İhlâs (اخلاص) kelimesi Arapça da hulûs kökünden gelmekte olup arınmak, saflaşmak, halis olmak manalarına gelmektedir (Ateş, 2000, 21/535). Gösterişi bırakmak; taatta, ibadette samimi olmak manalarını içeren Arapça bir kelimedir (Cebecioğlu, s. 298).

Sözlük manalarında ise ihlâs; saf, temiz, halis tutmak, karşılık beklememek, her türlü şüpheden uzak durmak (Ateş, 21/535); bir şeyi, kendisine karışmış ve bulaşmış olan şeylerden arındırmak, ayrıştırmak, kurtarmak ve sadece kendisi yapmak (Ekin, 2002, s. 147); halis, temiz, doğru ve temiz sevgi, gönülden gelen dostluk, samimiyet, doğruluk, bağl1lık (Develioğlu, 2017, s. 498), içten duyulan sevgi, yalansız yapmacıksı gönülden inanma ve inanç (Kard, 1971, 6/231) şekillerinde tanımlanmaktadır.

Bunlara ek olarak, ihlâs bir şeyi halis kılmak, halis olmak ve özünü alıp seçmek anlamları da taşımakta (Karagöz vd, 2007, s. 299); bir şeyi içine karışmış ve değerini düşürmüş olan başka şeylerden temizleyip arındırmak saflaştırmak (Ateş, 21/536) manalarına da gelmektedir.

Lûgatta taatlerde gösterişi terk etmek olarak ifade edilen ihlâs ıstılahî manada kalbin saflığını bozan karışmış kirlerden onu temizlemektir (Cürcânî, 1997, s. 15); iman, ibadet, itaat, ahlak, amel, dua gibi her türlü dinî görevleri, halkın övme ve beğenmesini, yerme ve kınamasını düşünmeksizin sırf Allah için iyi ve halis bir niyetle yapmak, şirk, nifak, riya gibi kötü hasletlerden uzak durmak, söz, fiil ve davranışlarında samimi ve dosdoğru olmak demektir (Karagöz vd, s. 299).

İhlâs; kalbinde Allah'dan başkasına yer bırakmamak, kalbini Allah'a ortaklık eden her türlü şeyden uzak tutmak, kalbinin sevgilisi, tek gayesi Allah olmak demektir (Gazzalî, 4/684). Hem düşünce hem davranış hem de amel boyutunda bireyin beyninde, kalbinde ve davranışlarında sadece tek amacının Allah rızası olması ve bu amaç doğrultusunda ibadetleriyle, kulluk bilinciyle, herhangi bir şek ve şüpheye düşmeden şirksiz, tevhid üzere (Ekin, s. 148) bir yaşam ile hakikî kul olma bilincine götürecek en önemli kavramlardandır.

Ameller için Allah'tan başka şahit istememek anlamına da gelen ihlâs kavramı ile kişi amellerini kirlerden arındırmalıdır. Allah ile kul arasında bir perde olan ihlâsı ne melekler bilip yazabilir ne de şeytan onu bozabilir (Cürcânî, 1997, s. 15). Bu doğrultuda ihlâsın hakîkati Allah dışında ki her şeyden uzak olmaktır( İsfahânî, 2010, s. 354).

Âyet-i kerîmeleri ve hadis-i şerifleri ihlâs kavramı bazında incelediğimizde ihlâsın önemi amel ve kalb dünyamızda çok ayrı bir yere nüfuz etmektedir. Tüm niyet, davranış ve fiiliyatların ana noktasının ihlâs olduğunu gördügümüz gibi, onlara anlam katan, değerli kılan ya da aynı zamanda eksikliğinde de tüm maddî ve manevî dünyamızı değersizleştiren de bir olgudur.

"Hâlbuki onlar Allah'a, O'nun dininde ihlâs ve samimiyet erbabı ve muvahhitler olarak, ibadet etmelerinden, namazı dosdoğru kılmalarından, zekâtı vermelerinden başkasıyla emrolunmamışlardı. En doğru din de bu idi” (El- Beyyine 98/5). 
Bu ayet-i kerimede Allah-u Teâlâ'nın vurguladığg ve sadece kullarından istediği samimi bir niyetle, sadece O'na kulluk etmesidir. Bu kulluğu da kalbinde başka hiçbir şey bulundurmadan, ibadetlerini Allah'ın rızasını umarak ve yalnızca O'ndan dileyerek yerine getirmeli; her yerde her şeyde $\mathrm{O}$ varmışçasına halis düşünce ve fiillerle O'na sığınarak yaklaşabilmeyi istemelidir.

“Kitap'ta Musa'yl an! Gerçekten o, ihlâsa erdirilmiş, bir resul ve bir peygamberdi" (ElMeryem 19/51).

Bu ayet ile işarî tefsir geleneğinin temsilcilerinden Kuşeyrî; Hz. Musa'nın ihlâsla nitelenmesini, Allah dışında bir şeye teveccüh etmemesini, kınayanın kınamasına aldırmamasını, dünyevî bir hazzı elde etmek gibi bir arzuyla vazifesinde gevşeklik gösterip ilahî bir hakikati görmezlikten gelmemesini vurgulamış, ibadetlerin özünü açıklamıştır (Ekin, s. 150).

Diğer bir ayette de Allah-u Teâlâ: "İhlâs benim sırlarımdan bir sırdır onu, sevdiğim kulumun kalbine yerleştiririm" buyurarak Allah rızasını amaç edinmenin ve bu uğurda çabalamanın sonunda Allah'ın sevdiği kul olma şerefine nail olunabileceğini ve sırlarına da ulaşılabileceğini vurgulamaktadır. İrade, niyet ve amel dengesinin ser'̂̂, ilmî ve irfanî olarak sağlanması gerektiği de bu ayette karşımıza çıkabilmektedir (Gazzalî, 4/676).

Ayet-i kerimelerden anladığımız gibi ihlâs Allah'ın lütfu olan ve aynı zamanda da kişinin kalbine nüfuz ederek amellerin değerini arttıran çok önemli bir kavramdır. Peygamber Efendimiz(sav) de ihlâs kavramını açıklarken önemli tanımlamalarda bulunmakta, insanlara yol göstererek kalbî ve amelî kazanımların oluşmasını amaçlamaktadır.

"Dinin göstergesi Allah için ihlâsl olmak, ilmin göstergesi de Allah'tan korkup çekinmektir." (Dünya, 2006, s. 15). Allah rızasına niyet edip davranışlarında rızayı gözetmek, amellerinde ihlâsı bulmaya çalışmak, dünyevî ve uhrevî kazanımlar için kulun dikkat etmesi gereken önemli iki unsurdur. Nitekim Peygamber Efendimiz(sav)'e "iman nedir? diye sorulduğunda, ihlâstır" (Çetin, 1984, s. 37) buyurarak imanın ruhunun ihlâs olduğunu vurgulamaktadır. Amellerin niceliğinden ziyade niteliğini etkileyen ihlâs kavramı ümmetin kurtuluşuna vesile olacağı gibi (Nesâî, Cihâd, 43), kalbîn meylini Allah'a yöneltmekte, nefsanî istek ve arzulardan kişiyi koruyabilmektedir (İbn Mace, Mukaddime, 18). Amellerini ihlâsla yapan mü'minler ihlâsın hakikatine ererek gösterişten ve nefsin kötü arzularından uzak durarak hakiki rızaya varmayı amaçlamaktadırlar (Mekkî, s. 37).

Kur'an-1 Mübin'in gösterdiği ihlâs çizgisi ve Peygamber Efendimiz Hz. Muhammed Mustafa (sav) nın örnek ve yol göstericiliğiyle hayatımıza nakşetmemiz gereken ihlâs olgusu zahirî ve batinî anlamları sebebiyle hem şeriat hem de hakikat ehillerince üzerinde önemle durulmuştur. İhlâsın yaşantısal olarak içselleştirilerek hem amellere hem de ibadetlere yerleştirilmesi gerektiğini savunan önemli şahsiyetlerde de amaç hep aynıdır; halis bir kul olarak, gönül bağıyla, şeksiz ve şüphesiz ebedî mutluluğa götürecek Allah rızasına nail olabilmek adına tüm ibadet ve davranışlarda ölçülü, temiz ve duru bir sevgi bağı oluşturmaktır. Büyük zatlar ihlâs kavramı üzerinde titizlikle durmuş, kalbi riyadan, gösterişten uzak tutarak halis bir kul olma çabasında olma gayretini her kulun yaşaması gerektiğini savunmuşlardır.

Niyetler ve ameller; çıkar, menfaat, dünyevî istekler doğrultusunda nefsanî olabileceği gibi, rahmanî olarak da sadece Allah rızası için de olabilmektedir. Niyeti ve ameli bu seviyeye çıkarabilen tutum da ihlâsdır ve niyet ile ihlâs arasındaki kuvvetli olan bu bağ ile birey kulluk vazifesiyle Rahman'a aracısız ulaşabilmektedir. Nitekim ihlâsın ameli kötülük ve ayıplardan temizlediğini söyleyen (Gazzalî, 4/679) Yahya b. Muâz er Râzî (v. 258/872), ihlâsın önemini vurgularken aynı zamanda da niyet ve amellerin rotasının her daim Hakk'a çıkması gerektiğini göstererek niyetin halis olması gerektiğini göstermektedir.

Kişinin gösteriş, dünyalık istekler için öncelediği niyetleri kişiyi bu dünya nimetlerine götürürken, rızadan uzaklaştırmakta, riyaya düşürmektedir. Birey riya afetine yakalandığında ise her ne niyetle olursa olsun amelleri, düşünce ve davranışları kurtuluş sebebi olamayacaktır. Onun için ön şart olarak riyadan kurtulmayı murad etmek ve bu yönde çaba sarf etmek gerekmektedir. Bu çabanın karşılığında da elbet kişinin karşısına halis niyet ve ihlâs kavramları çıkacaktır. Ebu Osman el-Hîrî'nın (v. 298/910) vurguladığı üzere ihlâs; devamlı olarak Allah'ı düşünmek ve O'na bakmakla mahlûku 
unutmaktır. Allah'1 önceleyerek yapılan her iş kişiye fayda sağlayabileceği gibi kalbî olarak da düzelmesini, gelişmesini sağlayacak, riyadan uzaklaştıracaktır (Kuşeyrî, 2016, s. 291). Önemli olan halis niyetle sırf Allah rızasını gaye edinip samimiyetle O'na yönelmek ve ihlâsı yakalamak olmalıdır ki kişi riya afetinden kurtulabilsin ve hakiki amaca yönelebilsin.

\section{Tasavvuf ilminde niyet ve ihlâs arasındaki iliş̧i}

Zahirî ve Bâtıni yönlerini ele almak için niyet ve ihlâs kavramlarını ayrıntılı bir şekilde ele aldıktan sonra Bâtıni yorumlarını daha iyi analiz edebilmek adına tasavvuf ilminde bu iki kavramın ne manaya geldiğini, aralarındaki bağlantıları incelemek faydalı olacaktır. $\mathrm{Bu}$ ilim dalının ileri gelen şahsiyetlerin düşüncelerine yer verilecektir. Niyet ve ihlâsın önemini, yaşantımıza dâhil etme durumumuzu, onların görüş ve fikirlerinden yararlanarak ayrıntılı bir tafsilata girmeye çalışmak faydalı olacaktır.

“Allah'ın rizâsını kazanma arzusuyla ve O'nun hükmüne tâbi olmak üzere fiile yönelen irade" (Selvi, 2018, s. 258) şeklinde tarif edilen niyet; kulluğun sırrı, amelin özü, ruhu ve direğidir. Amellerin Allah katında değerli veya değersiz sayılması, dünyevî işlerdeki sonuçların ne olacağı konusundaki değerlendirmeler bireyin niyeti yönünde olacağı için niyet hem kalbî hem de fiilî olarak büyük önem taşımaktadır (Dönmez, 33/172).

İhlâs da; temiz itikat, ibadet ve itaatte sadece Allah'a yönelmek, ikiyüzlü olmamak, her şeyi Allah rızası için yapmak, yapılan ameli Allah’tan başkasının görmesini istememek demektir (Acar, 1995, s. 17). Allah rızası için ve sadece Allah'ın görmesini dilediği ameller bireyde kalbî uyanıklık hali oluşturacağı için bireyin kalbini bu konuma hazırlaması gerekmektedir. Bu hazırlanış kişinin belirli bir eğitimden geçmesiyle elde edilebileceği gibi aynı zamanda da niyetleri halis hale getirerek de olabilmektedir. Bu kalbî unsurlar niyet ve ihlâs kavramlarının batınî yönünü ifade edeceği için tasavvuf ilmi çerçevesinde ele almak kavramların öz manasını anlamak ve iki kavram arasında bağlantı kurabilmek adına önemlidir.

İlk mutasavvıflardan Haris el-Muhasibi (v. 243/857) riya ve ihlâs konusunda yazılan en eski ve ayrıntılı eser konumundaki "er-Riaye" isimli eserinde ihlâsın şartlarını kalbe bağlamıştır. Kalbin iyilik ve ihlâs üzere olması, bozulmaktan korunması gerekmektedir. Kalbin kötüye meyletmemesi içinde Allah için olanı almak, başkası için olanı terk etmek gerekmektedir. Muhasibi'ye göre zaten kalbin görevi iman ve tevbeden sonra amelleri Allah için yapmak, şüphe anında hüsn-ü zanna sarılmak ve Allah'a güven beslemek, azabından korkmak ve mükâfatından ümit beslemektir (Muhasibî, s. 46, 55, 58). Kalb, aslî vazifesini kaybetmediği takdirde, dünyevî işlerde özünü unutmadığında zaten kişi ihlâs üzere olacak ve kalbi onu Allah'a götürecektir.

Muhasibî’ye göre niyet ve ihlâs arasında bir bağlam oluşturduğumuzda kişinin niyetinde hem dilde hem kalpte hem de tüm organlarda Allah'ın hoşlanmadığı şeylerden uzak durması, sevdiği şeylere tüm uzuvlarını yöneltmek olmalıdır. Niyette gayenin ve amelde temelin ihlâs olduğu düşüncesinden hareketle Allah'ın vazife olarak koyduklarını Allah'a saygıdan dolayı yapmak, yasaklarından da kaçınmak, Allah'ın vaad ettiği mükâfatları ümit etmek ve niyetini kişinin bu doğrultuya çevirip, bunlarda ihlâslı olması gerekmektedir (Gülbudak, 1981, s. 56).

Mekkî’ye (v. 386/996) göre ise Allah Teâlâ, bir kula niyeti bahşettiği zaman ihlâsı da bahşeder ve o kişiyi niyetine gelebilecek âfetlerden korur. Bu, onun için hazırlanmış bir lütuftur. Diğer amelleri de kendisi için biriktirilip saklanır (Mekkî, s. 40). Niyetinde ihlâsı elde etmek; ihlâsın zıddı olan şeyleri kalpten çıkarmak, diğer maksatları ve gayeleri terk etmekle olur. İstek ve arzuların sayısı çok olsa da kişi niyet ve kast ile bunu tek şeye indirebilir. Niyetin sadece Allah Teâlâ'nın rızasını kazanmaya bağlanması ile kul amellerde ihlâsı elde etmiş olur (Mekkî, s. 70). Niyet ve ihlâs arasında çok etkin bir bağlantı kuran Mekkî niyeti Allah rızası olan her kişinin ihlâsı yakaladığını vurgulayarak kişinin kalbî afetlerden korunması gerektiğini, niyetini bozmadan ihlâs üzere yaşamasını söylemektedir.

Tasavvuf ilmini sistemleştiren ve tasavvufî kavramları öz bir şekilde ele alan Kuşeyrî (v. 4651072) ihlâsı; taat ve ibadette sadece Allah-u Teâlâ'yı kastetmek (Kuşeyrî, s. 289) şeklinde ifade eder. İhlâsa erişebilmek için kişinin niyetinin sadece Allah'a yaklaşmak olması gerektiğini söylemekte ve bunu da kişi hem ibadetleri hem de taatleriyle göstermelidir. Ayrıca ihlâs, Allah'tan başkasına amelini göstermemeyi gerektirecek kadar hassas ve önemli noktaları olan bir kavramdır. Niyetinde ve bu niyet 
doğrultusunda oluşacak amelinde birey; yaptığı amellerin karşılığında hiçbir şey beklemeden sadece Allah'ın rızasını gözeterek ve dünyevî, uhrevî hiçbir beklentiye girmeden ihlâsı yakalamayı gaye edinmelidir (Kuşeyrî, s. 289).

Hüccetü'l-İ̀slâm Gazzâli (v. 505/1111) İhya adlı eserinde kalbin övülen hallerinden birisinin de ihlâs olduğunu söylemektedir. İhlâs, yalnız kulluk hakkını yerine getirmek için yapılan ibadette tecelli etmektedir. İhlâsın manası dil ile halin birleşmesidir. İhlâs demek kişinin hem yalnız olduğu ortamda hem de kalabalık bir ortamda dahi halinin, kalbinin, huzurunun değişmemesidir (Gazzâlî, 1/1,59, 411, 588, 735, 873). Gazzâlî, ihlâsın mahallinin kalb olduğunu vurgulayarak kalbi Allah rızasına meylettirmenin elzem olduğunu söylemektedir. Niyet-ihlâs ilişkisine farklı bir yorum getiren Gazzâlî bu iki kavramı irade kavramıyla ele almış, ihlâsa amellerin arka planında yer alan iradenin analizini yaparak ulaşllabileceğini söylemektedir. "Ömrünün bir anını sirf Allah rızâsını gözeterek geçirebilen kişi kurtuluşa erer" diyerek ihlâsın kurtuluşa erme vesilesi olduğunu dile getirmiştir (Gazzâlî, 4/379, 380). Kişinin iradesinin niyetine, niyetin gayesinin de ihlâsa götürüp götürmeyeceğini, iradî hareketle halis bir niyet ya da dünyevî bir niyete çeviren kişi, neyi amaç ettiğine göre iradesini yönlendirmektedir. Hakkanî iradeye sahip kişi niyetini ilk önce halisane (Gazzâlî, 4/680-690; Muhâsibî, s. 234-235) k1lıp sonrasında amellerini Hakk rızası için yaparak ihlâsa erebilecek, dünyevî arzulardan sıyrılmayı iradî olarak murad ederek kurtuluşa erebilecektir.

Bazı âlimler de ihlâsı; "hareket, sakinlik, ayakta duruş, oturuş, her türlü işin ve sözlerin sırf Allah için olmasıdır" şeklinde tarif etmektedirler. Kişinin işinde Allah'tan gayriyi görmez hale gelmesi ihlâsın en son noktasıdır (Cebecioğlu, s. 298). Bu âlimlerden Tâceddin es-Sübkî (v. 771/1370) niyetle ihlâs arasında bir ilişki olduğunu ve ihlâsın niyetin ötesinde ve niyete ilâve bir durumu yani niyetin kemal derecesini temsil ettiğini, dolayısıyla ona göre daha özel olduğunu belirtmektedir. Bir diğer âlime göre ise niyet ve ihlâsın eş anlamlı olduğunu ve bunların birbirinden ayrı düşünülemeyeceğini ileri sürmektedir (Dönmez, 33/172). Niyet ve ihlâs kavramları arasındaki özde aynı ama ifadede çeşitlilik gösteren bu bağlantılar, iki kavramın da birbiriyle alakalı, iç içe geçmiş kavramlar olduğunu gösterirken asıl gayenin Hakk rızasını kazanmak düşüncesi hâkimdir.

"Müceddid-i elf-i sân̂̂" (hicrî II. binyılın müceddidi) olarak bilinen İmam Rabbanî (v. 1034/1624) ihlâsı bütün fiillerde, sözlerde, duruşlarda ve davranışlarda zorla ve bir yapmacık olmadan meydana gelen bir olgu olarak tarif etmektedir. O'na göre yapmacık ve zorlamaya dayanan ihlâs için bir devam söz konusu değildir. Devamın olabilmesi için zorlamanın az gönüllüğün çok olması, rıza ile yola çıkılması gerekmektedir. Bu mertebe genellikle Allah'ın yüksek mertebedeki veli kulları içindir çünkü onlar yaptıkları her işi Allah için yaparlar, kendi nefsleri için yapmazlar (Rabbânî, 2011, 1/59). Buradan yola çıkarak nefs ve onun amansız istekleri ihlâs konusunda engel teşkil etmektedir. Kişi nefsini dizginleyebildiği, riyadan kaçabildiği, halis niyetle yola çıkabildiği takdirde ihlâsa adım adım yaklaşmakta, tüm amel, ibadet, duygu ve düşüncelerini Allah'ın rızasını umarak halis niyetle yapmaya ve kontrol etmeye başlamaktadır.

Mevlânâ Celâleddîn-i Rûmî’nin (v. 672/1273) niyet ve ihlâsa dair sözleriyle (Rûmî, 2017; Rûmî, 2015) bahsimizi bitirecek olursak eğer:

"Cenneti âlet edevat ile yapmamışlardır. Orası amellerden; iyi, sâlih amellerden ve hâlis niyetlerden yapılmiştır."

"Sana bütün davranışlarında ihlâs gerektir; ta ki Rabb-i Ecel senin amelini kabul ede... Zira ihlâs, taat kuşunun kanadıdır; siz kanatsız felah semtine nasıl uçabilirsiniz ki!"

Cennet'ül Âlâ'nın anahtarı olan, hâlis bir niyetle kalbimizden çıkarak tüm amellerimizin anlam kazanmasını, Rabb-u Teâlâ'ya ulaşmasını sağlayan ihlâs kavramı kuş misali kuşları esas özgürlüğe, esas kulluğa götürecek anahtar, temel kavramlardandır. Hâlis niyetin ihlâsa götürdüğü bu yolda kavramlar arası denge, tasavvufî hal ve durumlar kulun kalbinden başlayarak tüm uzuvlarını Allah rızasına göre şekillendirecek, Muhabbetullah'a vâsıl olacaktır.

\section{Sonuç}

Niyet ve ihlâs kavramlarının zahirî ve bâtinî manalarını, aralarındaki bağlantıyı ve iradî hareketleri, amellerin içerik ve yönünü detaylı şekilde ele alan âlimlerin ve tasavvuf ehlinin ileri 
gelenlerine göre öncelik halis niyetle amellerini Allah rızası için yerine getirmek, sadece rızayı önceleyip, Allah-u Teâlâ'yı tekleyerek ihlâsa erişmeyi hedeflemektir. Bunun için kişinin kendisindeki ihlâs kazanımına engel olacak davranışlardan sıyrılmak, nefsini tezkiye edebilmek, halis niyet ve hüsnü zan ile amelleri güzelleştirmek ve en son noktada da tüm ibadet ve taatlerinde ihlâsa sarılarak Allah'1n rızasını, sevgisini ve saygısını kazanmak için çabalamak en önemli vazifelerdendir.

Makalemizde niyet ve ihlâs kavramlarının çok çeşitli manalarını hem lugatî, hem şerrî hem de tasavvufî yönlerden açıklamaya çalışarak kavramlarımızın her türlü anlamsal boyutunu ele almaya gayret gösterdik. Peygamber Efendimiz (sav) halis niyet ve ihlâs kavramlarını önemle vurgularken, yetiştirdiği sahabeler ve onların ardından gelenler de bu iki kavramın önemini yadsımadan ilk önce kalblerine sonra hayat ve amellerine geçirmeyi amaçlamışlar, halis niyetten yoksun, salih amelsiz ve ihlâssız bir yaşamın boşa kulluk olduğunu söylemişlerdir. Bunun için her bir sahabenin, mutasavvıfın sözü konumuza ışık tutarken, tasavvufî açıdan da batinî ve derunî manasını anlamamızı sağlamışlardır.

Muhasibî'den Mekkî'ye, Mekkî'den Kuşeyrî’ye, Kuşeyrî’den Gazzâlî’ye Gazzâlî’den İmam Rabbanî̀ye tasavvuf ilminin ileri gelenlerinin görüşleri çalışmamızın çatısını oluştururken; makalemizin konusu olan niyet ve ihlâs kavramlarına getirdikleri yorumlarla, zahirî ve batinî manalarıyla, bireylerin hayatlarına ne şekilde uygulayabileceklerine yer verilmiştir. Halis olmayan bir niyetten doğan amelin Allah'ın rızasına uygun olmadığı, bu niyete nefsanî unsurların dâhil olması kişiyi ihlâstan uzaklaştırdığı gibi yaratılış amacına aykırı bir yaşama sebebiyet verdiği için kulluk görevinin sekteye uğradığı ve esas kurtuluşa erilemeyeceği sonucuna ulaşılmıştır.

İradî bir kuvvetle alınan halis niyet salih amellerle süslendiğinde, ihlâs ile Allah'a yaklaşıldığında ulaşılacak "kulluk"; akıl ile kalbin birleşmesinden oluşacak gücün hem kişinin zahirinde (dışa yansıyan düşünce, fiil ve amellerinde) hem batınında (iç dünyasında, kalbindeki duygu, hislerinde) olumlu bir etki yaparak esas Müslüman kimliğini karşımıza çıkarmaktadır. Bu kimlik zahirî olarak tek başına yetmemekte, batinî boyutuyla da hayata anlam katmakta, amelleri ruhanî ve rahmanî boyuta ulaştırmaktadır. Şirkten ve riyadan uzak Allah'ın rızasını umarak yapılan her türlü amel halis bir niyetle olmakta, bu niyetin hakikati de bireyi ihlâs mertebesine ulaştırarak manevî kurtuluşa erdirmektedir. 
Kayseri Üniversitesi Sosyal Bilimler Dergisi, Cilt 2, Say1: 2, Aralık 2020, 114-122

Kayseri University Journal of Social Sciences, Vol 2, No: 2, December 2020, 114-122

\section{KAYNAKÇA}

Acar, G. (1995). Kur'an-ı Kerim'de ihlâs (Tez No. 41644) [Yüksek lisans tezi, Ankara Üniversitesi]. Yükseköğretim Kurulu Ulusal Tez Merkezi'nden edinilmiştir.

Afifi, Ebu'l Ala (1996). Tasavvuf İslam'da manevi hayat. (Çev. Ekrem Demirli, Abdullah Kartal). İz Yayınc1lik.

Cebecioğlu, E. (2009). Tasavvuf deyimleri ve terimleri sözlüğü. Ağaç Kitapevi.

Cürcanî, A. (1997). Tarifat Arapça-Türkçe terimler sözlüğü. (Çev. Arif Erkan). Bahar Yayınları.

Çetin, İ. (1984). Edeble varlş lütufla dönüşs tasavvufí adab. Adab Yayınları.

Develioğlu, F. (2017). Osmanlıca-Türkçe ansiklopedik lûgat. Aydın Kitapevi, 33. Basım.

Dönmez, İ. K. (2007). Türkiye Diyanet Vakfi İslam Ansiklopedisi. TDV Yayınları.

Dünya, İbn Ebi'd (2006). Hadislerde ihlâs ve niyet. (Çev. Yusuf Özbek). Ocak Yayıncılık.

Ekin, Y. (2002). İhlâs kavramının semantik analizi. Tasavvuf Dergisi. 3/2, 147-160.

Erginli, Z. (2006). Metinlerle tasavvuf terimleri sözlüğ̈̈. Kalem Yayınevi.

Etimoloji (t.y.). Niyet. https://www.etimolojiturkce.com/kelime/niyet.

Gazzâlî, Ebu Hamid b. Muhammed (2012). İhya'u Ulumi'd Din. (Çev.Ahmet Serdaroğlu). Bedir Yayınevi.

Görmez, V. Çolak S. R. (2019, Mayıs). Davranışlarımızı Yönlendiren Düşünceler. https://bilimgenc. tubitak.gov.tr/makale/davranislarimizi-yonlendiren-dusunceler

Gülbudak, A. (1981). İslam'da ihlâs. (Yayınlanmamış lisans tezi, Ankara Üniversitesi İlahiyat Fakültesi).

İsfahânî, R. (2010). Müfredat Kur'an kavramları sözlügü. (Çev. Abdulbaki Güneş, Mehmet Yolcu). Çıra Yayınları.

Karagöz, İsmail vd. (2007). Dinî kavramlar sözlüğü. DİB Yayınları.

Kur'an Yolu Meâli (2014). (Çev. Hayrettin Karaman, İbrahim Kâfi Dönmez, Mustafa Çağrıcı, Sadrettin Gümüş). Diyanet İşleri Başkanlığı.

Kuşeyri, A. (2016). Tasavvuf ilmine dair Kuşeyri risalesi. (Çev. Süleyman Uludağ). Dergâh Yayınları.

Lugatım (t.y.). İhlâs. http://lugatim.com/s/ihlas

Lugatım (t.y.). Niyet (t.y.). http://lugatim.com/s/niyet.

Mekkî, Ebu Tâlib (2019). Kûtu’l kulûb kalplerin azı̆̆ı. (Çev. Dilaver Selvi, Ali Kaya). Semerkand Yayınları.

Muhasibî, H. (2012). er Riâye li Hukûkillah kalb hayatı. (Çev. Abdülhakim Yüce). Işık Yayınları.

Öğük, E. (2013). Allah'a yaklaşmada isabetli olan ve olmayan yollar. Usûl, 20/2, 81-112.

Rabbani, İ. (2011). Mektubat-ı Rabbani. (Çev. Abdulkadir Akçiçek). Yasin Yayınevi.

Rumî, M. C. (2017). Mesnevî şerhi Tâhirü’l Mevlevi. (Çev. Şefik Can). Şamil Yayınevi.

Rumî, M. C. (2015). Divan-ı kebir. (Çev. Abdülbaki Gölpınarlı). Türkiye İş Bankası Yayınları.

Selvi, D. (2018). Beyzavî tefsirinde tasavvuf. Nizamiye Akademi.

Türkiye Diyanet Vakfi (2000). İhlâs. Türkiye Diyanet Vakfi İslam Ansiklopedisi. 